\title{
Relationship between Insulin-Like Growth Factor 1 and Bone Mineral Density in Men Aged over 65 Years
}

\author{
İbrahim Ertuğrula M. Akif Karan ${ }^{\mathrm{b}} \quad$ Ayşe Karan ${ }^{\mathrm{c}}$ Nilgün Erten ${ }^{\mathrm{a}}$ \\ Halim İşsever ${ }^{d} K_{\text {Kvanç Çefle }}{ }^{a}$ Dilşad Sindelc \\ Departments of a Internal Medicine, ${ }^{b}$ Geriatrics, ${ }^{c}$ Physical Medicine and Rehabilitation and \\ dPublic Health, Istanbul Faculty of Medicine, Istanbul University, Istanbul, Turkey
}

\section{Key Words}

Insulin-like growth factor 1 - Bone mineral density Osteoporosis · Elderly men

\begin{abstract}
Objective: To determine the association between insulin growth factor 1 (IGF-1) and bone mineral density (BMD) in men over 65 years of age. Subjects and Methods: Forty-one male patients aged $65-88$ years without a history of drug use or illness which is known to affect BMD were enrolled in the study. The control group consisted of 20 healthy men (19-62 years old). An immunoradiometric assay was used to measure IGF-1 levels. Dual-energy Xray absorptiometry was used to determine BMD at the proximal femur and lumbar spine. A detailed questionnaire was used to assess the epidemiological findings. Results: The men over 65 years of age had a lower mean IGF-1 level (102.04 \pm 36.65 vs. $196.62 \pm 84.86 \mathrm{ng} / \mathrm{ml}$ ) and a lower mean BMD at the femoral neck, trochanter and intertrochanteric zones, Ward's triangle and total hip than the controls. No statistically significant association was observed in the BMD of the lumbar vertebrae between the patients and controls. IGF-1 levels were strongly and negatively correlated with age $(p<0.0001$,
\end{abstract}

\section{KARGER}

Fax +41613061234

E-Mail karger@karger.ch

www.karger.com
(C) 2003 S. Karger AG, Basel

1011-7571/03/0124-0231\$19.50/0

Accessible online at:

www. karger.com/mpp $r=-0.82)$. Logistic regression analysis showed that low IGF-1 levels were strongly associated with osteopenia of the total hip, femoral neck, trochanter and intertrochanteric zone. Conclusion: The finding shows that low serum IGF-1 levels were associated with an increased risk of hip osteopenia and, hence, at least partly responsible for the osteopenia observed in men aged 65 years or over.

Copyright $@ 2003$ S. Karger AG, Basel

\section{Introduction}

Osteoporosis is an important cause of mortality and morbidity in the elderly [1]. Although bone loss is common in both elderly men and women, osteoporosis has been regarded mainly as a woman's disease, and research on osteoporosis has so far involved mostly women. However, longitudinal studies have shown that in men, the loss in bone mass is considerably accelerated during aging, 5$10 \%$ in every 10 years [2-4], a figure which is much higher than that estimated in cross-sectional studies, $1-3 \%$ for every 10 years $[5,6]$.

Hypogonadism is a well-established cause of OP in men [7], but the role of testosterone in age-related bone loss has not yet been established. Other factors related to 
the attainment of peak bone mass and maintenance of skeletal integrity throughout life are genetic factors, physical activity, nutrition, weight loss, tobacco smoking, exposure to sunlight, some drugs and the presence of chronic disease $[7,8]$.

Insulin-like growth factor 1 (IGF-1) disorder has been associated with the etiology of idiopathic osteoporosis and the IGF-1 level has been correlated with bone mineral density (BMD) of the lumbar spine [9, 10]. IGF-1 is a peptide which is structurally similar to insulin, and its activity is dependent on growth hormone. It is abundant in the circulation and plays an important role in carbohydrate, protein and bone metabolism. IGF-1 has been shown to be important in the differentiation, maturation and recruitment of osteoblasts. One of the most important endocrinological alterations associated with aging is the fall in IGF-1 concentrations. It may be hypothesized that low concentrations of this peptide may contribute to age-related bone loss. Therefore in the present study, we have investigated the correlation between IGF-1 levels and BMD in men 65 years old or over.

\section{Subjects and Methods}

Forty-one men (65-88 years old) were selected by systematic sampling from male patients who were admitted to the outpatient clinics for various reasons between March and December 2000; every consecutive fifth patient was enrolled in the study. The 22 control men (19-62 years old) were selected randomly from 56 healthy male hospital staff whose average body mass index $(26.29 \pm 3.8)$ was approximately the same as that of the study group $(25.45 \pm 2.37)$. Exclusion criteria included: (1) a history of disease that affected bone metabolism such as malignancy, renal or liver disease, endocrinological disorders, malabsorption, malnutrition, congenital diseases, neurological or psychiatric disorders and delayed puberty; (2) drugs that influence bone density such as estrogen, anticonvulsants, glucocorticoid therapy, thyroid hormones, antituberculous drugs and recent use of aluminium-containing antacids, and (3) patients with severe kyphosis, scoliosis or vertebral crush fractures based on the findings of conventional X-ray pictures. The Mediterranean Osteoporosis Study questionnaire [11] was used to determine epidemiological factors that might affect osteoporosis. Calcium intake was calculated according to a 24-hour diet history.

An immunoradiometric assay method (DSL-5600 IGF-I IRMA, Diagnostic Systems Laboratories Inc., Tex., USA) was used to measure IGF-1 levels. The procedure included a simple extraction step in which IGF-1 was separated from its binding protein in serum. This step was considered to be essential for the accurate determination of IGF-1. The intra-assay and interassay coefficients of variation were $2.8 \%($ mean value $=55.35 \mathrm{ng} / \mathrm{ml})$ and $3.6 \%($ mean value $=255.9$ $\mathrm{ng} / \mathrm{ml})$, respectively.

The BMD of the proximal femur and lumbar spine were measured using a dual-energy absorptiometry diagnostic system (QDR1000 densitometer).
Statistical analysis was performed using Student's t test and $\chi^{2}$ test. Pearson correlation coefficients were calculated to determine the relationships between BMD, hormone levels and biochemical markers. Linear regression analysis was used to evaluate the contribution of epidemiological and biochemical markers, hormones and IGF-1 to variance in BMD.

\section{Results}

The men aged 65 years and over had a lower mean IGF-1 level and a lower mean BMD at the femoral neck, trochanter and intertrochanteric zones, Ward's triangle and total hip than the control group. Bone loss was most remarkable in Ward's triangle. There was no difference in the BMD values of $\mathrm{L}_{1}-\mathrm{L} 4$ vertebrae between the study and control groups (table 1).

Using the WHO's criteria [12] for osteopenia ( $\mathrm{t}$ values between -1 and -2.5 ) and osteoporosis ( $\mathrm{t}$ values $<-2.5$ ), more male patients had a low $\mathrm{t}$ value $(\mathrm{t}<-1)$ or reduced BMD of the proximal femur than the control group. On the other hand, in the subjects with a normal $(t \geq-1)$ and low $(t<1)$ value, the BMD of the $\mathrm{L}_{1}-\mathrm{L}_{4}$ vertebrae was not significantly different between the patients and controls (table 2).

The IGF-1 levels were strongly and negatively correlated with age $(\mathrm{p}<0.0001, \mathrm{r}=-0.82)$, but not with height, weight or body mass index.

There were mild and positive correlations between IGF-1 and BMD measured at the femoral neck, trochanter, intertrochanteric zone and Ward's triangle $(\mathrm{p}<$ $0.0001, \mathrm{r}=0.58 ; \mathrm{p}<0.0001, \mathrm{r}=0.48 ; \mathrm{p}<0.0001, \mathrm{r}=0.48$; $\mathrm{p}<0.0001, \mathrm{r}=0.51$, respectively) controlled for age, body mass index, calcium intake, smoking, activity and alcohol intake. There were also mild and negative correlations between age and BMD values measured at the intertrochanteric zone, trochanter, Ward's triangle, femoral neck and total hip $(\mathrm{r}=-0.38, \mathrm{p}=0.002 ; \mathrm{r}=-0.35, \mathrm{p}=0.007 ; \mathrm{r}=$ $-0.47, \mathrm{p}<0.0001 ; \mathrm{r}=-0.56, \mathrm{p}<0.0001 ; \mathrm{r}=-0.41, \mathrm{p}=$ 0.001 , respectively). The BMD measured at $\mathrm{L}_{1}-\mathrm{L}_{4}$ vertebrae was not correlated with IGF-1 and age.

In the study group, logistic regression analysis ('forward LR') showed that IGF-1 levels lower than the median level of $97.2 \mathrm{ng} / \mathrm{ml}$ were strongly associated with osteopenia $(\mathrm{t}<-1)$ of the total hip, trochanter and $\mathrm{L}_{1}-\mathrm{L}_{4}$ vertebrae (table 3). These findings suggest that low IGF-1 levels increase the risk of osteopenia of the total hip, trochanter and $\mathrm{L}_{1}-\mathrm{L}_{4}$ vertebrae 28.8, 12.8 and 3.9 times, respectively. When the study group and controls were analyzed together, logistic regression ('forward') showed that the lower IGF-1 levels were associated with osteope- 
Table 1. BMD and IGF-1 levels in the study and control groups (means $\pm \mathrm{SD}$ )
Table 2. The number of subjects with a normal $(\mathrm{t} \geq-1)$ and low $(\mathrm{t}<1)$ BMD in the study and control groups
Table 3. The effect of IGF-1 on BMD measured at various locations for the study group

\begin{tabular}{lccc}
\hline & $\begin{array}{l}\text { Study group } \\
(\mathrm{n}=41)\end{array}$ & $\begin{array}{l}\text { Control group } \\
(\mathrm{n}=20)\end{array}$ & $\mathrm{p}$ \\
\hline BMD, g/cm ${ }^{2}$ & & & \\
$\quad$ Spine L1-L4 & $0.933 \pm 0.164$ & $0.952 \pm 0.079$ & $>0.05$ \\
$\quad$ Femoral neck & $0.727 \pm 0.113$ & $0.849 \pm 0.109$ & $<0.0001^{*}$ \\
$\quad$ Trochanter & $0.655 \pm 0.111$ & $0.714 \pm 0.100$ & $0.041^{*}$ \\
$\quad$ Intertrochanteric zone & $1.044 \pm 0.165$ & $1.162 \pm 0.119$ & $0.006^{*}$ \\
$\quad$ Ward's triangle & $0.547 \pm 0.167$ & $0.687 \pm 0.153$ & $0.002^{*}$ \\
$\quad$ Total hip & $0.886 \pm 0.147$ & $1.00 \pm 0.137$ & $<0.0001^{*}$ \\
\hline IGF-1, ng/ml & $102.04 \pm 36.65$ & $196.62 \pm 84.86$ & $<0.0001^{*}$ \\
\hline
\end{tabular}

* Significant.

\begin{tabular}{|c|c|c|c|c|c|}
\hline & \multicolumn{2}{|c|}{ Study group $(n=41)$} & \multicolumn{2}{|c|}{ Control group $(n=20)$} & \multirow[t]{2}{*}{$\mathrm{p}$} \\
\hline & normal & low BMD & normal & low BMD & \\
\hline Spine L1-L4 & 16 & 25 & 5 & 15 & $>0.05$ \\
\hline Femoral neck & 4 & 37 & 12 & 8 & $0.00003^{*}$ \\
\hline Trochanter & 23 & 18 & 17 & 3 & $0.025 *$ \\
\hline Intertrochanteric zone & 21 & 20 & 19 & 1 & $0.0007 *$ \\
\hline Ward's triangle & 5 & 36 & 12 & 8 & $0.00009^{*}$ \\
\hline Total hip & 21 & 20 & 16 & 4 & $0.031^{*}$ \\
\hline
\end{tabular}

* Significant.

\begin{tabular}{|c|c|c|c|c|c|c|c|}
\hline & \multirow[t]{2}{*}{ B } & \multirow{2}{*}{$\begin{array}{l}\text { Standard } \\
\text { error }\end{array}$} & \multirow{2}{*}{$\begin{array}{l}\text { Degrees } \\
\text { of } \\
\text { freedom }\end{array}$} & \multirow{2}{*}{$p$} & \multirow{2}{*}{$\begin{array}{l}\text { Odds } \\
\text { ratio }\end{array}$} & \multicolumn{2}{|c|}{$0.95 \mathrm{CI}$} \\
\hline & & & & & & lower & upper \\
\hline Hip & 3.36 & 0.904 & 1 & $<0.0001^{*}$ & 28.80 & 4.892 & 169.538 \\
\hline Trochanter & 2.54 & 0.758 & 1 & $0.001 *$ & 12.80 & 2.896 & 56.578 \\
\hline $\mathrm{L}_{1}-\mathrm{L}_{4}$ vertebrae & 1.36 & 0.682 & 1 & $0.045^{*}$ & 3.91 & 1.028 & 14.874 \\
\hline
\end{tabular}

* Significant. nia of the total hip, trochanter, intertrochanteric zone and femoral neck; low IGF-1 levels increase the risk of osteopenia of the total hip, trochanter, intertrochanteric zone and femoral neck 12.7, 22.4, 14.1 and 10.0 times, respectively (table 4). No other comparisons concerning BMD measured at other locations were statistically significant.
Both models were adjusted for all the variables such as serum phosphorus and dehydroepiandrosterone sulfate levels, urinary phosphorus excretion, urinary hydroxyproline excretion or intake of cheese, fish and meat in the recent past that were different between the study group and controls. 
Table 4. The effect of IGF-1 on BMD measured at various locations for all cases, patients and controls

\begin{tabular}{|c|c|c|c|c|c|c|c|}
\hline & \multirow[t]{2}{*}{ B } & \multirow{2}{*}{$\begin{array}{l}\text { Standard } \\
\text { error }\end{array}$} & \multirow{2}{*}{$\begin{array}{l}\text { Degrees } \\
\text { of } \\
\text { freedom }\end{array}$} & \multirow{2}{*}{$\mathrm{p}$} & \multirow{2}{*}{$\begin{array}{l}\text { Odds } \\
\text { ratio }\end{array}$} & \multicolumn{2}{|c|}{$0.95 \mathrm{CI}$} \\
\hline & & & & & & lower & upper \\
\hline Hip & 2.54 & 0.647 & 1 & $<0.0001^{*}$ & 12.79 & 3.600 & 45.500 \\
\hline Femoral neck & 2.30 & 1.090 & 1 & 0.034 & 10.01 & 1.182 & 84.866 \\
\hline Trochanter & 3.10 & 0.700 & 1 & $<0.0001^{*}$ & 22.40 & 5.672 & 88.458 \\
\hline Intertrochanteric zone & 2.65 & 0.655 & 1 & $<0.0001 *$ & 14.16 & 3.920 & 51.151 \\
\hline
\end{tabular}

* Significant.

\section{Discussion}

Although our sample data were limited, the results indicate that osteopenia of men is much more frequent than was previously estimated. However, it is difficult to assess BMD in older patients because of the high prevalence of degenerative joint disease (DJD). Osteophytes, facet sclerosis and other manifestations associated with DJD may cause BMD [13]. Our patients had DJD with variable degrees of severity. Therefore, it is possible that DJD might have contributed to the apparently similar BMD of $\mathrm{L}_{1}-\mathrm{L}_{4}$ vertebrae in the study and control groups (table 4).

Sugimoto et al. [14] reported that, in women with low IGF-1 levels, the risk of femoral, vertebral and midradial osteoporosis was increased thereby indicating the importance of IGF-1 as a risk factor for fractures in the elderly. Langlois et al. [15] reported that in women, BMD of the femur, radius and $\mathrm{L}_{2}-\mathrm{L}_{4}$ vertebrae was significantly lower than those of men. They observed that IGF-1 levels in both sexes showed a tendency to decrease with advancing age. A multivariate analysis indicated that in women, serum IGF-1 levels correlated positively with the BMD values of the hip, radius and all of the lumbar vertebrae. This correlation was independent of weight, height, protein intake, smoking, mobility, changes in body weight and body mass index. High BMD values of each of the 3 femoral zones and the spine were associated with raised serum IGF-1 levels [15]. Decreased serum concentrations of IGF-1 were associated with an increased risk of osteoporotic fractures in postmenopausal women [16]. In contrast to the report of Langlois et al. [15], our results show a similar correlation also in men. However, their study did not show any correlation between IGF-1 levels and BMD values in men as the present finding seems to indicate.

Several studies reported that in women, a high level of IGF-1 correlates with increased BMD [17-19], whereas osteoporosis [20] and vertebral fractures [14] are associated with low IGF-1 levels. Likewise, in elderly men IGF-1 levels correlate with BMD $[19,21]$ and BMDs of the spine and femoral neck are closely related with IGF-1 levels [22]. A relevant observation is the low IGF-1 levels in young men with idiopathic osteoporosis [10,23].

Presently, the mechanisms by which IGF levels affect BMD are not clear. It has been reported that menopausal and postmenopausal bone loss correlates with IGF-1 and estradiol levels [3, 18]. Similar to the BMD values, in elderly men IGF-1 levels are higher than in age-matched women $[15,19]$. We did not find a correlation between IGF-1 levels and sex hormones in the present study.

It has been reported that in men with idiopathic osteoporosis, IGF-1 levels correlate with vertebral BMD and may contribute to the osteoporosis of lumbar vertebrae [10]. Although IGF-1 levels correlated with the BMD of the femoral neck and total hip, we observed no correlation between IGF-1 and the BMD of $\mathrm{L}_{1}-\mathrm{L}_{4}$ vertebrae. The number of male patients with a low $\mathrm{BMD}$ of $\mathrm{L}_{1}-\mathrm{L}_{4}$ vertebrae was rather increased ( 25 of 41 old men); however, there was no difference between the two groups in this regard. On the other hand, after excluding other factors, logistic regression analysis revealed the effect of IGF-1 levels on the BMD of $\mathrm{L}_{1}-\mathrm{L}_{4}$ vertebrae; low IGF-1 levels were found to be associated with a 3.9-fold increase in the risk of osteopenia of $\mathrm{L}_{1}-\mathrm{L}_{4}$ vertebrae, whereas the same figure for the total hip and trochanteric zone was 28.8 and 12.8 , respectively. However, in the logistic regression analysis model, when all the data from the patient and control group were pooled, the effect of IGF-1 levels on $\mathrm{L}_{1}-\mathrm{L}_{4}$ vertebrae was negligible.

While the BMD of $\mathrm{L}_{1}-\mathrm{L}_{4}$ vertebrae was higher than that of the total hip, trochanteric zone and Ward's triangle, it was lower than the value of the intertrochanteric zone. These findings are in agreement with other studies reporting that the vertebral BMD is lower than those of 
the femoral neck, trochanter, Ward's triangle and radius in elderly men $[15,24]$.

The main source of circulating IGF-1 is the liver. Its release is mainly dependent on the hepatic activity of growth hormones [25]. Men with idiopathic osteoporosis have lower IGF-1 levels. It has been reported that shortterm growth hormone stimulation with arginine infusion followed by oral administration of $L$-dopa does not increase IGF-1 and insulin-like growth factor binding protein 3 levels in men of 31-68 years of age with idiopathic osteoporosis [26]. It has been shown that growth hormone is not impaired in osteoporotic men with low IGF-1 levels. Rosen et al. [27] reported that low serum IGF-1 levels in men with idiopathic osteoporosis were associated with homozygosity for a specific allele of the IGF-1 microsatellite (192/192) and suggested that IGF-1 levels were related to a polymorphism in the IGF-1 gene. It is possible that various local and hormonal factors that influence IGF-1 gene expression may also be responsible for the low IGF-1 levels associated with aging. Further studies are needed to show the impact of those factors on the expression of the IGF-1 gene.

Interpretation of this study has some limitations. The relationship between IGF-1 and BMD was evaluated cross-sectionally and not longitudinally. Therefore the assumption that IGF-1 levels are relatively stable in the elderly [28] may not be true. Equally important, the study and control subjects consisted of only Turkish men, and, therefore, it may be misleading to extrapolate the results to other ethnic groups. Considering that IGF-1 and BMD levels decrease with advancing age, the wide age distribution of our study population (65-88 years) and controls (19-62 years) might have contributed to the strong positive correlation between BMD and IGF-1. IGF binding proteins influence the activity of IGF-1. Unfortunately we were not able to analyze IGF-1 binding protein levels.

In the present study, we found that urinary hydroxyproline levels were significantly lower in the study group than in the control group. Hydroxyproline excretion is influenced by nutritional status and extraskeletal catabolical processes that lower the specificity and the sensitivity of the test; it has been reported that in this respect urinary pyridinoline and deoxypyridinoline analysis are more reliable [29].

\section{Conclusion}

The results show that in men aged 65 years and over, the frequency of osteopenia is more marked, and IGF-1 levels correlate with the BMD of the proximal femur. Low serum IGF-1 levels were associated with an increased risk of hip osteopenia thereby indicating that low IGF-1 levels were partly responsible for the osteopenia observed in elderly men.

\section{References}

1 Ringe JD, Dorst A: Osteoporosis in males: Pathogenesis and clinical classification in osteoporosis. Proc 4th Int Symp Osteoporosis, Hong Kong, March 1993, pp 84-85.

2 Meier DE, Orwoll ES, Jones JM: Marked disparity between trabecular and cortical bone loss with age in healthy men: Measurement by vertebral computed tomography and radial photon absorptiometry. Ann Intern Med 1984; 101:605-612.

3 Davis JW, Ross PD, Vogel JM, Wasnich RD: Age-related changes in bone mass among Japanese-American men. J Bone Miner Res 1991; 15:227-236

4 Tobin JD, Fox KM, Cejku ML: Bone density changes in normal men: A 4-19 year longitudinal study. J Bone Miner Res 1993;8:102.

5 Hannan MT, Felson DT, Anderson JJ: Bone mineral density in elderly men and women: Results from the Framingham osteoporosis study. J Bone Miner Res 1992; 7:547-553.
6 Mazess RB, Barden HS, Drinka PJ, Bauwens SF, Orwoll ES, Bell NH: Influence of age and body weight on spine and femur bone mineral density in US white men. J Bone Miner Res 1990;5:645-652.

7 Orwoll ES: Osteoporosis in men. Endocrinol Metab Clin North Am 1998;27:349-367.

8 Sherman SS, Tobin JD, Hollis BW, Gundberg CM, Roy TA, Plato CC: Biochemical parameters associated with low bone density in healthy men and women. J Bone Miner Res 1992;7: 1123-1130.

9 Johansson AG, Eriksen EF, Lindh E, Langdahl B, Blum WF, Lindahl A, Ljunggren O, Ljunghall S: Reduced serum levels of the growth hormone-dependent insulin-like growth factor binding protein and a negative bone balance at the level of individual remodeling units in idiopathic osteoporosis in men. J Clin Endocrinol Metab 1997;82:2795-2798.
10 Kurland ES, Rosen CJ, Cosman F, McMahon D, Chan F, Shane E, Lindsay R, Dempster D, Blezikian JP: Insulin-like growth factor-I in men with idiopathic osteoporosis. J CIin Endocrinol Metab 1997;82:2799-2805.

11 Dequeker J, Ranstam J, Valsson J, Sigurgevisson B, Allander E: The Mediterranean Osteoporosis (MEDOS) Study questionnaire. Clin Rheumatol 1991;10:54-72.

12 WHO Assessment of Osteoporotic Fracture Risk and Its Role in Screening for Postmenopausal Osteoporosis. WHO Technical Report Series. Geneva, WHO, 1994.

13 Kanis JA: Osteoporosis. Oxford, Blackwell Science, 1994.

14 Sugimoto T, Nishiyama K, Kuribayashi F, Chihara K: Serum levels of insulin-like growth factor (IGF) I, IGF-binding protein (IGFBP)-2, and IGFBP-3 in osteoporotic patients with and without spinal fractures. J Bone Miner Res 1997;12:1272-1279. 
15 Langlois JA, Rosen CJ, Visser M. Hannan MT, Harris T, Wilson PWF, Kiel OP: Association between insulin-like growth factor 1 and bone mineral density in older women and men: The Framingham Heart Study. J Clin Endocrinol Metab 1998;83:4257-4262.

16 Gamero P, Sornay-Rendu E, Delmas PD: Low serum IGF-1 and occurrence of osteoporotic fractures in postmenopausal women. Lancet 2000;355:898-899.

17 Boonen S, Lesaffre E, Dequeker J, Aerssens J, Nijs J, Pelemans W, Bouillon R: Relationship between baseline insulin-like growth factor-I (IGF-I) and femoral bone density in women aged over 70 years: Potential implications for the prevention of age-related bone loss. J Am Geriatr Soc 1996;44:1301-1306.

18 Romagnoli E, Minisola S, Carnevale V, Scarda A, Rosso R, Scarnecchia L, Pacitti MT, Maz zuoli G: Effects of estrogen deficiency on IGF-I plasma levels: Relationship with bone mineral density in perimenopausal women. Calcif Tissue Int 1993;53:1-6.

19 Barret-Connor E, Goodman-Gruen D: Gender differences in insulin-like growth factor and bone mineral density association in old age The Rancho Bernardo Study. J Bone Miner Res 1998;13:1343-1349.
20 Ravn P, Overgaard K, Spencer EM, Christiansen $\mathrm{C}$ : Insulin-like growth factors I, and II in healthy women with and without established osteoporosis. Eur J Endocrinol 1995;132:313319.

21 Rudman D, Drinka PJ, Wilson CR, Mattson DE, Scherman F, Cuisinier MC, Schultz S: Relations of endogenous anabolic hormones and physical activity to bone mineral density and lean body mass in elderly men. Clin Endocrinol (Oxf) 1994;40:653-661.

22 Fall C, Hindmarsh P, Dennison E, Kelligray S, Barker D, Cooper C: Programming of growth hormone secretion and bone mineral density in elderly men: A hypothesis. J Clin Endocrinol Metab 1998;83:135-139.

23 Reed BY, Zerwekh JE, Sakhaee K, Breslau NA, Gottschalk F, Pak CYC: Serum IGF-I is low and correlated with osteoblastic surface in idiopathic osteoporosis. J Bone Miner Res 1995; 10:1218-1224.

24 Kenny AM, Prestwood KM, Marcello KM, Raisz LG: Determinants of bone density in healthy older men with low testosterone levels. J Gerontol 2000;55A:M492-M497.
25 Jones JI, Clemmons DR: Insulin-like growth factors, and their binding proteins: Biological actions. Endocr Rev 1995;16:3-34.

26 Kurland ES, Chan FKW, Rosen CJ, Blezikian JP: Normal growth hormone secretory reserve in men with idiopathic osteoporosis and reduced circulating levels of insulin-like growth factor-1. J Clin Endocrinol Metab 1998;83: 2576-2579.

27 Rosen CJ, Kurland ES, Vereault D, Adler RA, Rackoff PJ, Craig WY, Witte S, Rogers J, Bilezikian JP: Association between serum insulin growth factor-I (IGF-I) and a simple sequence repeat in IGF-I gene: Implications for genetic studies of bone mineral density. J Clin Endocrinol Metab 1998;83:2286-2290.

28 Rosen CJ, Mohan S, Hunter J, Vereault D, Baylink DJ: Seasonal changes in bone density and in serum IGFBP-4 levels are associated with calcium intake and parathyroid hormone (PTH) concentrations in elderly New England women. J Bone Miner Res 1997;12:S166.

29 Robins SP, Black D, Paterson CR, Reid DM, Duncan A, Seibel MJ: Evaluation of urinary hydroxypyridinium crosslink measurements as resorption markers in metabolic bone disease. Eur J Clin Invest 1991;21:310-315. 